\title{
Effect of irrigation water containing arsenic on elemental composition of bean and lettuce plants cultivated in calcareous sandy soil
}

\author{
Sirat Sandii ${ }^{1,2}$, Péter Dobosy ${ }^{1}, K^{\prime}$ risztina Kröpfl' ${ }^{1}$ Anna Füzy ${ }^{3}$, Mihály Óvári ${ }^{1}$ and Gyula Záray ${ }^{1,2^{*}}$
}

\begin{abstract}
Background: The uptake of arsenic by vegetables from soil irrigated with arsenic enriched groundwater poses a major health hazard. The edible portion of these vegetables transfer arsenic to the human beings. The uptake of arsenic was studied in bean (Phaseolus vulgaris L.) and lettuce (Lactuca sativa L.) in a controlled greenhouse pot culture with calcareous sandy soil as substrate. The plants were irrigated with water containing sodium arsenate at concentrations $0.1,0.25$ and $0.5 \mathrm{mg} \mathrm{L}^{-1}$. The total arsenic concentration of the different plants parts was determined by ICP-MS, following microwave-assisted acid digestion. The change in plant biomass production and essential macroelements (Mg, P, K) and microelements concentration ( $\mathrm{Fe}, \mathrm{Mn}, \mathrm{Cu}, \mathrm{Zn}$ ) was also studied.

Results: The As concentration in the bean was in the order: root>stem>leaf $>$ bean fruit and in lettuce: root>leaves. At the highest dose $\left(0.5 \mathrm{mg} \mathrm{L}^{-1}\right)$ the As concentration in the bean fruit and lettuce leaves was $22.1 \mathrm{\mu g} \mathrm{kg}^{-1}$ and $1207.5 \mathrm{~g} \mathrm{~kg}^{-1}$ DW, respectively. Increasing As concentration in the irrigation water resulted in decreased edible biomass production in bean, while in lettuce the edible biomass production increased. Neither plant exhibited any visible toxicity symptoms. No significant change was observed in the macro and microelements concentration. The total and the water-soluble arsenic in soil amounted to $3.5 \mathrm{mg} \mathrm{kg}^{-1}$ and $0.023 \mathrm{mg} \mathrm{kg}^{-1}$, respectively. The transfer factor was found to increase with increase in the As treatment applied. The transfer factor range for bean from root to fruit was 0.003-0.005, and for lettuce from root to leaves was 0.14-0.24.
\end{abstract}

Conclusion: Considering the FAO-WHO recommended maximum tolerable daily intake (MTDI) limit of $2.1 \mathrm{\mu g} \mathrm{kg}^{-1}$ body weight, and the biomass production, both plants should not be cultivated at As treatment level higher than $0.1 \mathrm{mg} \mathrm{L}^{-1}$.

Keywords: Arsenic/irrigation water/ uptake/ transfer factor/calcareous sandy soil/vegetables

\section{Introduction}

Climate change increases the frequency and duration of droughts resulting in a significant reduction in agricultural yields. Intensifying irrigation may be the solution for this problem. However, when using groundwater, it is necessary to check its chemical composition with particular regard to toxic elements such as arsenic. Arsenic

\footnotetext{
*Correspondence: zaray@chem.elte.hu

${ }^{1}$ MTA Centre for Ecological Research, Danube Research Institute, Karolina út 29-31, Budapest H-1113, Hungary

${ }^{2}$ Cooperative Research Centre of Environmental Sciences, Eötvös Loránd

University, Pázmány Péter sétány 1/A, Budapest H-1117, Hungary

Full list of author information is available at the end of the article
}

contamination of the groundwater and soil is a major environmental toxicity issue, especially in South-east Asia and in countries like China, Hungary, Iceland, Mexico, Chile, Argentina, Brazil, and USA (Santra et al. 2013; Sarkar \& Paul 2016). Arsenic concentration in the groundwater in Hungary ranges between $0.02-0.1 \mathrm{mg} \mathrm{L}^{-1}$ (Varsanyi \& Kovacs 2006). Arsenic release into the environment can occur naturally from the soil parent materials and anthropogenically through irrigation, mining, combustion of fossil fuels and use of arsenical pesticides (Ascher et al. 2009). The use of As-rich groundwater for irrigation can lead to accumulation of high levels of As in the soil and

(c) The Author(s). 2019 Open Access This article is distributed under the terms of the Creative Commons Attribution 4.0 International License (http://creativecommons.org/licenses/by/4.0/), which permits unrestricted use, distribution, and 
plants, impacting crop productivity and increasing As concentration in the food chain (Lazaro et al. 2018). Arsenic exists in the environment in both organic and inorganic forms, but the inorganic species, arsenate and arsenite are abundant in the soil and groundwater (Abedin et al. 2002; Sarkar \& Paul 2016). Phytoavailable As depends on total As and bioavailable As, $\mathrm{pH}$, redox potential, organic matter, free $\mathrm{CaCO}_{3}, \mathrm{Fe}, \mathrm{Mn}$ and $\mathrm{P}$, soil microbes and soil type (Brammer \& Ravenscroft 2009; Saifullah et al. 2018). As being a nonessential element for plants is transported through transport channels of other elements. Arsenate being chemically similar to phosphate is up-taken by phosphate transporters into the root and shoot. Arsenite and methylated As species are up-taken through aquaglyceroporins, predominantly nodulin 26-like intrinsic protein (NIP). The xylem to phloem loading and subsequent transfer to seeds is not very well understood but recent research in Arabidopsis revealed the involvement of inositol transporter (INTs) (Awasthi et al. 2017). Effects of As toxicity on plants include growth inhibition, leaf wilting, curling and burning, chlorosis and necrosis (Shaibur et al. 2008). The major As intake pathway for humans is oral, from drinking water and food (through the groundwater-soil-plant system) (Lu et al. 2010; Bakhat et al. 2017). The recommended As concentration in drinking water is $10 \mu \mathrm{g} \mathrm{L}^{-1}$ (WHO 1993). The JECFA recommended maximum tolerable daily intake (MTDI) limit in food was $2.1 \mathrm{\mu g} \mathrm{kg}^{-1}$ body weight (FAO-WHO 1988). This value was withdrawn later because studies indicated that inorganic As in range $2-7 \mu \mathrm{g} \mathrm{kg}^{-1}$ bw per day increased incidence of lung, urinary bladder and skin cancer. The (JECFA 2011) and (EFSA 2009) have both proposed a range of As concentration values considered to be safe $\left(0.1-3 \mu \mathrm{g} \mathrm{kg}^{-1}\right.$ bw per day and $0.37-1.22 \mu \mathrm{g} \mathrm{kg}^{-1}$ bw per day, respectively). Since these values have not been officially accepted so we have used the previously accepted value of $2.1 \mu \mathrm{g} \mathrm{kg}^{-1}$ bw per day.

The As uptake by vegetables has been reported in various scientific literature (Warren et al. 2003; Das et al. 2004; Huq et al. 2006; Gusman et al. 2013a; UddhSoderberg et al. 2015). Plants have been found to accumulate the highest As concentration in the roots and the lowest in the edible parts ( $\mathrm{Lu}$ et al. 2010). Sadee et al. (2016) studied As uptake in broad bean (Vicia faba) in loamy soil, with soil and irrigation water As concentration $5.32 \mathrm{mg} \mathrm{kg}^{-1}$ and $1.06 \mu \mathrm{g} \mathrm{L}^{-1}$, respectively. The maximum concentration of As was observed in the roots (78\%) while the edible part contained only $0.133 \mathrm{mg} \mathrm{kg}^{-1} \mathrm{DW}$. The concentration was in the order of root $>$ leaf $>\operatorname{pod}>$ stem $>-$ bean. In a study by Stazi et al. (2016) on tomato grown in sandy soil irrigated with water containing As concentration of $0.1 \mathrm{mg} \mathrm{L}^{-1}$, As accumulation in roots was $8.11-$ $24.2 \mathrm{mg} \mathrm{kg}^{-1} \mathrm{DW}$, while the fruits contained $0.08-0.11$ $\mathrm{mg} \mathrm{kg}^{-1}$ DW. Juhasz et al. (2008) studied As in the edible parts of lettuce, radish and mung beans at concentration of $2 \mathrm{mg} \mathrm{L}^{-1}$ in hydroponic solution and found the concentration in the order: lettuce $\left(4.4 \mathrm{mg} \mathrm{kg}^{-1} \mathrm{DW}\right)<$ mung beans $\left(11.3 \mathrm{mg} \mathrm{kg}^{-1} \mathrm{DW}\right)<$ radish $\left(84.2 \mathrm{mg} \mathrm{kg}^{-1} \mathrm{DW}\right)$. Huang et al. (2006) studied vegetables grown in alluvial agricultural soil having $6.04 \mathrm{mg} \mathrm{kg}^{-1}$ As content and found the total As accumulation in the following order: eggplant $\left(3.8 \mu \mathrm{g} \mathrm{kg}^{-1}\right)<$ radish $\left(7.8 \mu \mathrm{g} \mathrm{kg}^{-1}\right)<$ cabbage $\left(7.8 \mu \mathrm{g} \mathrm{kg}^{-1}\right)<\quad$ cauliflower $\quad\left(14.6 \mu \mathrm{g} \mathrm{kg}^{-1}\right)<\quad$ lettuce $\left(23.3 \mu \mathrm{g} \mathrm{kg}^{-1}\right)<$ onion $\left(31.9 \mu \mathrm{g} \mathrm{kg}^{-1}\right)<$ leaf mustard $\left(59 \mu \mathrm{gg}^{-1} \mathrm{DW}\right)$. Some plants grown at high As concentration accumulate very high amounts of As which leads to stunted growth and loss of biomass production. Malik et al. (2012) in mung bean (Phaseolus aureus) grown hydroponically with As treatment $(2.5,5.0,10 \mu \mathrm{M})$ found the As accumulation to be $8.3,24.6$ and $40 \mathrm{mg} \mathrm{kg}^{-1} \mathrm{DW}$. The root and shoot growth were severely inhibited by 63 and $61 \%$ at $10 \mu \mathrm{M}$. In some tolerant plants As accumulates in the plant tissues at a very high concentration without any toxic effect on the plant. In lettuce, Gusman et al. (2013a) studied As (V) in a nutrient solution of concentration ranging $0.5-4 \mathrm{mg} \mathrm{L}^{-1}$, and found $\mathrm{As}(\mathrm{V})$ accumulation in leaves to be $34.94 \mathrm{mg} \mathrm{kg}^{-1} \mathrm{DW}$, at the highest treatment. Shaibur \& Kawai (2009), in Japanese mustard spinach (Brassica rapa) grown hydroponically with $\mathrm{NaAsO}_{2}$ at 0 , $0.5,2.5$ and $5 \mathrm{mg} \mathrm{L}^{-1}$ concentrations, found that the plant accumulated high levels of As at the highest treatment (shoot: $90 \mathrm{mg} \mathrm{kg}^{-1}$, root: $4840 \mathrm{mg} \mathrm{kg}^{-1} \mathrm{DW}$ ), unfit for human consumption without showing any toxicity symptoms except slight reduction in growth. The amount of As accumulated by the plant depends on the transfer factor, which is controlled by the plant species and the soil As concentration. Some plants can accumulate high amount of As and are called as hyperaccumulators (Oliveira et al. 2017).

Most of the studies conducted on As uptake have focused on uptake from soils or irrigation water with very high As content, but groundwater applied for irrigation in Hungary contains relatively lower As content $\left(0.02-0.1 \mathrm{mg} \mathrm{As} \mathrm{L}^{-1}\right)$. Therefore, a greenhouse experiment was carried out with the objective of determining the As effect on the growth of bean and lettuce, concentration and distribution of As in the plants, and the influence of As on the macroelements $(\mathrm{Mg}, \mathrm{P}, \mathrm{K})$ and microelements $(\mathrm{Fe}, \mathrm{Mn}, \mathrm{Cu}, \mathrm{Zn})$ profile of the edible plant part. The study also aimed at providing information to the growers about the As level in the irrigation water at which the plants would have maximum biomass productivity and minimum toxicity symptoms.

\section{Materials and methods}

\section{Plant cultivation}

Pot experiments were carried out in a climatic chamber at controlled temperature and light conditions (25$27^{\circ} \mathrm{C} / 17^{\circ} \mathrm{C}$ for day/night and $16 \mathrm{~h}$ lighting at $500 \mu \mathrm{mol} /$ $\left.\mathrm{m}^{2} / \mathrm{s}\right)$. Rhizoboxes were filled with calcareous sandy soil $(0.87 \mathrm{~L} / 1000 \mathrm{~g})$ and watered until $60 \%$ of field capacity. 
Pregerminated seeds of bean (Phaseolus vulgaris L., variety: Golden Goal) and lettuce (Lactuca sativa L., variety: "Mályus királya") were planted in each rhizobox and irrigated with tap water three times a week. Irrigation was supplemented by nutrient solution (Hoagland solution) and $\mathrm{Na}_{2} \mathrm{HAsO}_{4} .7 \mathrm{H}_{2} \mathrm{O}$ solution $(0.10,0.25$ and $0.50 \mathrm{mg} \mathrm{As} \mathrm{L}^{-1}$ ), from the third week. In bean, $630 \mathrm{ml}$ of Hoagland solution and $0.93 \mathrm{~L} \mathrm{Na}_{2} \mathrm{HAsO}_{4} \cdot 7 \mathrm{H}_{2} \mathrm{O}$ solution were added, while, in lettuce $780 \mathrm{ml}$ of Hoagland solution and $0.921 \mathrm{~L} \mathrm{Na}_{2} \mathrm{HAsO}_{4} .7 \mathrm{H}_{2} \mathrm{O}$ solution were added. A random experimental design was applied with 5 parallel plants in all treatments.

\section{Sampling and sample preparation}

Bean (root, stem, leaves, fruit) and lettuce (roots, leaves) plant parts were collected at the fruiting or mature stage. The samples were washed using deionized water, after which their fresh weights were obtained. All samples were then dried in a laboratory dryer at $40^{\circ} \mathrm{C}$ for $48 \mathrm{~h}$. The samples were homogenized using an agate pestle and mortar and then stored in a cool, dry place until analysis.

\section{Chemicals and reagents}

All chemicals used for the digestion procedure and elemental analysis were of analytical grade. Milli-Q water $\left(18 \mathrm{M} \Omega \mathrm{cm}^{-1}\right)$ produced by ELGA Ultra Purelab unit (VWS Ltd., High Wycombe, UK) was used throughout the experiment for dilutions and to prepare standards. Arsenic standards were prepared from sodium arsenate $\left(\mathrm{Na}_{2} \mathrm{HAsO}_{4} .7 \mathrm{H}_{2} \mathrm{O}\right)$ (Sigma Aldrich Ltd., Hungary). For analysis of other elements ICP-MS multi-element standard solution (110,580 Merck Ltd., Hungary) was applied. Accuracy of the analytical measurements was determined by using CRM, NIST 1573a Tomato leaf (National Institute of Standards and Technology, Gaithersburg, MD) as reference material. The total As recovery was $101 \%$, while the recoveries of the other macroelements and microelements were between 90 and 106\%.

\section{Elemental analysis of plant parts}

The dried plant samples were mineralized using the Analytik Jena Top Wave (Analytik Jena, Germany) microwave-assisted acidic digestion system. $0.3 \mathrm{~g}$ of the plant samples and $7 \mathrm{ml}$ of $\mathrm{HNO}_{3}(67 \%)$ and $3 \mathrm{ml}$ of $\mathrm{H}_{2} \mathrm{O}_{2}$ (30\%) were placed into the Teflon vessels of 100 $\mathrm{ml}$ each. The digestion procedure was performed applying a three-step heating program at temperatures of 90 , 160 and $200{ }^{\circ} \mathrm{C}$ for 20,15 and $15 \mathrm{~min}$, respectively. The digested samples were then transferred into volumetric flasks and the volume made up to $25 \mathrm{ml}$ with Milli-Q water. The concentrations of total and water-soluble arsenic as well as macroelements $(\mathrm{Mg}, \mathrm{P}, \mathrm{K})$ and microelements $(\mathrm{Fe}, \mathrm{Mn}, \mathrm{Cu}, \mathrm{Zn})$ were determined by inductivelycoupled plasma mass spectrometer (ICP-MS), Analytik
Jena Plasma Quant MS Elite (Analytik Jena, Germany) applying ${ }^{45} \mathrm{Sc},{ }^{89} \mathrm{Y}$ and ${ }^{115} \mathrm{In}$ isotopes as internal standards.

\section{Soil characterization}

Calcareous sandy top soil $(0-30 \mathrm{~cm})$ collected from Őrbottyán, Hungary $\left(47^{\circ} 40^{\prime} \mathrm{N}, 19^{\circ} 14^{\prime} \mathrm{E}\right)$ was used as substrate. The $\mathrm{pH}$ was measured according to the Hungarian Standard (MSZ-08-0206/2:1978) in 1:2.5 soil:1 M KCl and 1:2.5 soil: water suspension $12 \mathrm{~h}$ after mixing. The OM content was determined by the modified Walkley-Black method (MSZ-08-0452:1980). Plant-available P and K concentrations were determined after extraction with ammonium-acetate lactate (Egnér et al. 1960). The total N content was measured by Kjeldahl method (ISO 11261: 1995). The $\mathrm{NH}_{4}-\mathrm{N}$ and $\mathrm{NO}_{3}-\mathrm{N}$ concentrations were measured from $\mathrm{KCl}$ extracts according to the Hungarian Standard (MSZ 20135:1999). The $\mathrm{CaCO}_{3}$ content was measured using the Scheibler gas-volumetric method (MSZ-08-0206/2:1978). The pseudo total element concentrations were determined from the samples in aqua regia extract (MSZ 21470-50:2006) and the CEC values with modified method of Mehlich (MSZ-08-0215:1978). The water-soluble As concentration was determined in a soilwater ratio of 1:10 (MSZ 21470-50:2006).

\section{Transfer factor}

The transfer factor for As was calculated according to Dwivedi et al. (2010), where, S-As, L-As, F-As and R-As is the As concentration of the stem, leaves, fruit and root, respectively. $[\mathrm{TF}=(\mathrm{S}-\mathrm{As}+\mathrm{L}-\mathrm{As}+\mathrm{F}-\mathrm{As} / \mathrm{R}-\mathrm{As})]$.

\section{Statistical analysis}

Bartlett test was carried out to check the homogeneity of variance and Shapiro-Wilk normality test was done to check normal distribution. ANOVA was made in one factorial design, if the assumptions were fulfilled and Tukey multiple comparisons of means was applied as post hoc test. Kruskal-Wallis rank sum test was carried out in case of the assumptions were violated, combined with Nemenyi's test of multiple comparisons for independent samples as post hoc comparison. Statistical analysis was made by $\mathrm{R}$ statistical software ( $\mathrm{R}$ Core Team, 2018) and DescTools package (Signorell 2018).

\section{Results}

Physical and chemical properties of the soil

The physico-chemical parameters of the soil are given in Table 1 and some important ones are mentioned below. The $\mathrm{pH}$ of the selected calcareous sandy soil was 7.7. The soil contained $81 \%$ sand and $6 \%$ clay. The soil contained a high amount of Fe $\left(8.42 \mathrm{~g} \mathrm{~kg}^{-1}\right)$ and relatively low organic matter content. The water-soluble and total soil As content was $0.023 \mathrm{mg} \mathrm{kg}^{-1}$ and $3.50 \mathrm{mg} \mathrm{kg}^{-1}$, respectively. Only $0.66 \%$ of the As was water-soluble. 
Table 1 Physical-chemical parameters of the calcareous sandy soil

\begin{tabular}{|c|c|}
\hline $\mathrm{pH}-\mathrm{H}_{2} \mathrm{O}$ & 7.71 \\
\hline Organic matter (w/w\%) & 0.50 \\
\hline $\mathrm{CaCO}_{3}(\mathrm{w} / \mathrm{w} \%)$ & 16.1 \\
\hline $\mathrm{AL}-\mathrm{K}_{2} \mathrm{O}\left(\mathrm{mg} \mathrm{kg}^{-1}\right)$ & 48 \\
\hline $\mathrm{AL}-\mathrm{P}_{2} \mathrm{O}_{5}\left(\mathrm{mg} \mathrm{kg}^{-1}\right)$ & 129 \\
\hline Total N(w/w \%) & 0.067 \\
\hline $\mathrm{NH}_{4}-\mathrm{N}\left(\mathrm{mg} \mathrm{kg}^{-1}\right)$ & 3.2 \\
\hline $\mathrm{NO}_{3}-\mathrm{N}\left(\mathrm{mg} \mathrm{kg}^{-1}\right)$ & 3.2 \\
\hline CEC (Na meq/100 g) & 4.8 \\
\hline Total arsenic $\left(\mathrm{mg} \mathrm{kg}^{-1}\right)$ & 3.5 \\
\hline Water soluble arsenic $\left(\mathrm{mg} \mathrm{kg}^{-1}\right)$ & 0.02 \\
\hline
\end{tabular}

\section{Effect of different arsenic treatments on the bean and} lettuce plants growth

As toxicity symptoms were not observed in any plant at any treatment level. In bean, the biomass production was calculated at the fruiting stage to understand the effect of the As treatments on the bean fruit production (Fig. 1a). The plants parts displayed varying behavior at the As treatments of $0.1,0.25$ and $0.5 \mathrm{mg} \mathrm{L}^{-1}$. In case of roots, the biomass production as compared to the control, increased with the treatment applied (-1.3, 11.3 and $40.2 \%)$. In stem and leaves, the biomass production increased till the dosage of $0.25 \mathrm{mg} \mathrm{L}^{-1}$ and decreased at $0.50 \mathrm{mg} \mathrm{L}^{-1}$, indicating that a dosage of more than $0.25 \mathrm{mg} \mathrm{L}^{-1}$ is harmful to the plant. In the bean fruit, the biomass production displayed a negative trend to that of the root, depicting a drastic decrease in the biomass with increasing As treatment applied $(-10.4,-25.8 \%$ and $-27.2 \%)$. In lettuce, the biomass production was calculated at the mature stage when the leaves were large enough to be agriculturally profitable (Fig. 1b). The root biomass decreased at As treatment of $0.1 \mathrm{mg} \mathrm{L}^{-1}(-15.10 \%)$ and $0.5 \mathrm{mg} \mathrm{L}^{-1}(-3.12 \%)$ but increased at $0.25 \mathrm{mg} \mathrm{L}^{-1}$ As treatment (10.72\%). The leaves displayed a positive biomass production with increasing As concentration (9.83, 15.08 and $28.25 \%)$.

\section{Arsenic uptake by the plant parts}

The As concentration in bean and lettuce are displayed in Figs. 2a and b, respectively. The As concentration in all plant parts, of both plants, increased with increasing As concentration of the irrigation water. In bean (Fig. 2a), As concentration of the roots remained the highest, in the control as well as in all three treatments (2601.2, 3727.6, 3855.8 and $\left.4797.1 \mathrm{\mu g} \mathrm{kg}^{-1} \mathrm{DW}\right)$. The As concentration in all bean roots was significantly different. The lowest As concentration in As treated plants was in the bean fruit (9.7, 7.1 and $\left.22.1 \mu \mathrm{g} \mathrm{kg}^{-1} \mathrm{DW}\right)$. Arsenic concentration in the stem and leaves at all treatments was significantly different. In lettuce (Fig. 2b), the maximum As accumulation was observed in the roots (2139.6, 2704.9 and $4445.6 \mu \mathrm{g} \mathrm{kg}-1$ DW) and the minimum in leaves (301.1, 608.7 and $\left.1207.5 \mu \mathrm{gg}^{-1} \mathrm{DW}\right)$. In the control plants and the 0.1 and $0.25 \mathrm{mg} \mathrm{As} \mathrm{L}^{-1}$ treated plants, the root As concentration is not significantly different, but at $0.5 \mathrm{mg}$ As L ${ }^{-1}$ treatment the root As concentration was significantly higher. In leaves, As concentration was significantly different in all cases. Plants irrigated with $0.5 \mathrm{mg}$ As $\mathrm{L}^{-1}$ had about two-fold higher As concentration than

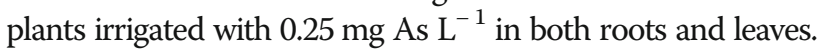
This indicated that at a higher As concentration in the irrigation water $\left(>0.25 \mathrm{mg} \mathrm{As} \mathrm{L}^{-1}\right)$ the As absorption and translocation by the plant increases.

\section{Effect of arsenic on the investigated macroelements and microelements profile in the edible plant part}

The change in concentration of essential macro and microelements in the bean fruit and lettuce leaves are listed in Table 2 and Table 3, respectively. In both plants the $\mathrm{Mg}$ concentration decreased with increasing As treatment. Compared with the control, $\mathrm{Mg}$ concentrations decreased by 6.77 and $11.7 \%$, in bean and lettuce, respectively, at 0.5 $\mathrm{mg}$ As $\mathrm{L}^{-1}$ treatment. The $\mathrm{Mg}$ concentration of lettuce leaves was about three-fold higher than the bean fruit. In bean, $\mathrm{P}$ concentration increased up to As treatment of 0.1 $\mathrm{mg} \mathrm{L}^{-1}$, but then decreased. Compared with the treatment at $0.1 \mathrm{mg} \mathrm{As} \mathrm{L}^{-1}$, the P concentration declined by $18.05 \%$. In lettuce the pattern was opposite, with $\mathrm{P}$ concentration initially decreasing at $0.1 \mathrm{mg} \mathrm{As} \mathrm{L}^{-1}$ and then increasing at higher As treatment. Compared with the treatment at $0.1 \mathrm{mg} \mathrm{As} \mathrm{L^{-1 }}$, the P concentration increased by $43.96 \%$. Compared to control, $\mathrm{K}$ concentration in bean increased (13.6\%), while in lettuce, $\mathrm{K}$ concentration decreased (28.86\%), with higher As treatment applied. Fe concentration in both bean and lettuce increased significantly (16.39 and $125.8 \%$, respectively) with higher As treatment, but in lettuce uptake was almost five-fold higher at $0.5 \mathrm{mg} \mathrm{L}^{-1}$. Mn shows an increasing tendency in both bean and lettuce (41.5 and $10.87 \%$, respectively), but the increase is more pronounced in case of bean. Mn concentration of bean was three to five-fold higher than that of lettuce. In both bean and lettuce $\mathrm{Cu}$ uptake varied slightly at all treatments, but bean $\mathrm{Cu}$ concentration was seven to tenfold higher than lettuce $\mathrm{Cu}$ concentration. $\mathrm{Zn}$ concentration in bean showed an increasing trend while in lettuce it does not change significantly. $\mathrm{Zn}$ concentration of bean was almost ten-fold higher than that of lettuce.

Means with the same letters in each row are not significantly different according to Tukey's test at 5\% level.

Means with the same letters in each row are not significantly different according to Tukey's test at 5\% level.

\section{Transfer factor}

The transfer factors for As in bean and lettuce are listed in Table 4. In bean, the TF from root to shoot was 0.11- 


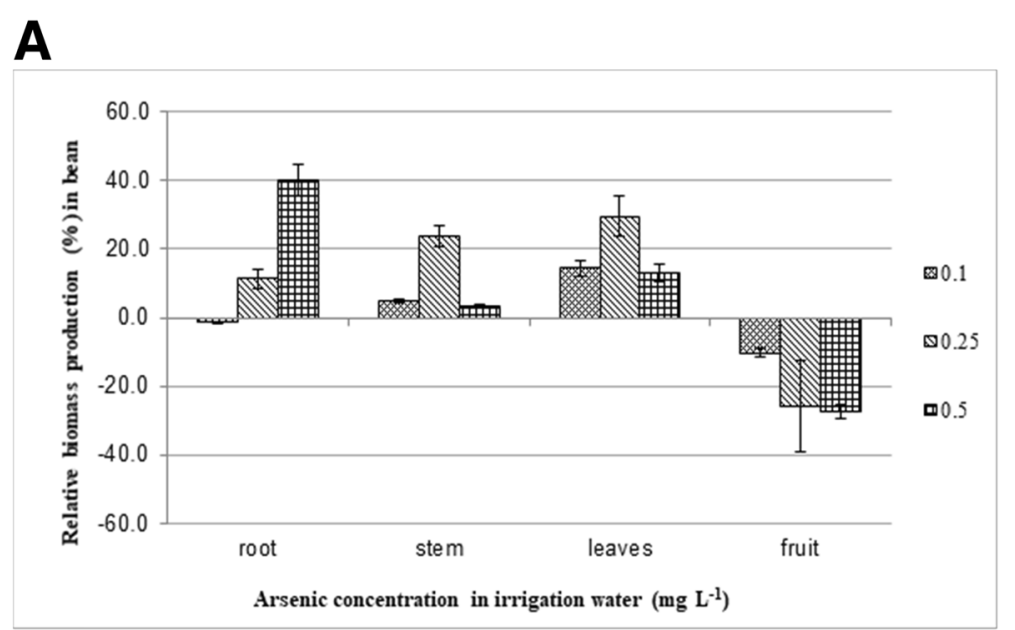

B

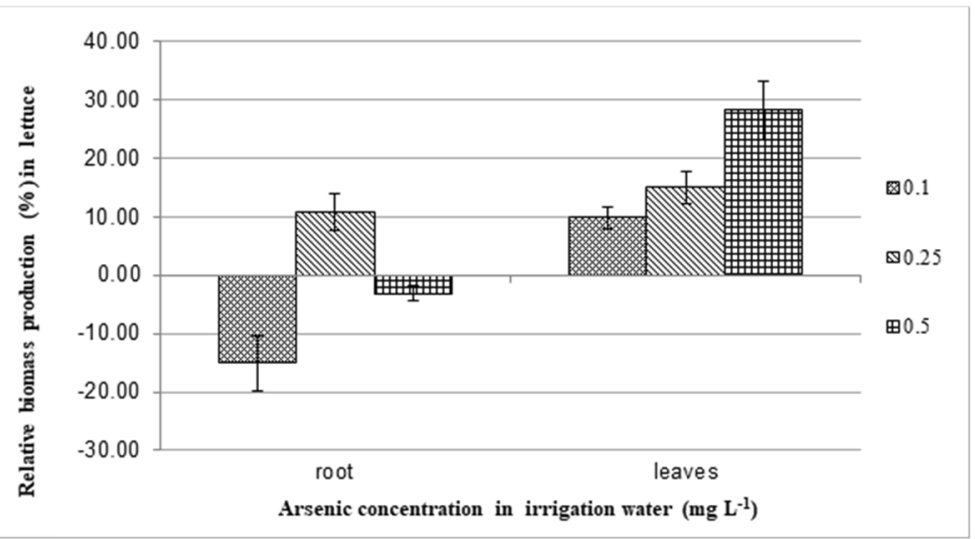

Fig. 1 Effect of various arsenic concentrations in the irrigation water on biomass production of the bean plant parts in the fruiting stage (a), and on the lettuce root and leaves in the final growth stage $(\mathbf{b})$, relative to the control samples. Bars indicate standard deviation

0.18 and from root to fruit was $0.003-0.005$. In lettuce, the TF from root to leaves was $0.14-0.24$. The TF from root to shoot/leaves is similar in both plants, while to fruit is very less.

\section{Discussion}

\section{Impact of soil texture on as uptake}

Soil texture determines As availability to plants as As is more mobile and bioavailable in sandy soils than clay soils. Availability of As is lower in fine textured soil like clay or silt, due to higher surface area for binding (Sahoo \& Kim 2013; Saifullah et al. 2018). In soil, As availability is less due to association with sulphides, oxides/hydroxides of $\mathrm{Al}$, $\mathrm{Fe}$, and $\mathrm{Mn}$, with $\mathrm{Al}-\mathrm{As}$ and Fe-As complexes being the dominant chemical forms (Mirza et al. 2014). In the current study only $0.66 \%$ of As was water-soluble, which could be due to the high amount of Fe. Amorphous Fe oxyhydroxides have a high adsorption affinity for inorganic As and can control bioavailable-As (Otero et al. 2016).
Effect of different arsenic treatments on the bean and lettuce plants growth

In the present study, the root biomass of bean increased while the fruit and shoot biomass decreased on application of As concentration of $0.5 \mathrm{mg} \mathrm{L}^{-1}$. This indicates that bean fruit is sensitive to higher As concentration, while the roots can remain unaffected and can grow despite accumulating large amount of As. Similar results were obtained by Melo et al. (2009) in castor bean (Ricinus communis cv. Guarany) where no impact on the root and shoot biomass was observed at $0.5 \mathrm{mg} \mathrm{L}^{-1}$, and no toxicity symptoms were observable even at $5 \mathrm{mg} \mathrm{L}^{-1}$. But, Stoeva et al. (2005) reported a decrease in the overall bean dry mass as well as reduction in shoot and root length in Phaseolus vulgaris L. at As concentrations of 2 and $5 \mathrm{mg} \mathrm{L}^{-1}$. In lettuce, the growth trend was opposite with the biomass of leaf increasing and root decreasing. Koo et al. (2011) reported lettuce roots to be more sensitive to As exposure than the leaves. Lettuce grows well in contaminated soils, despite accumulating large 


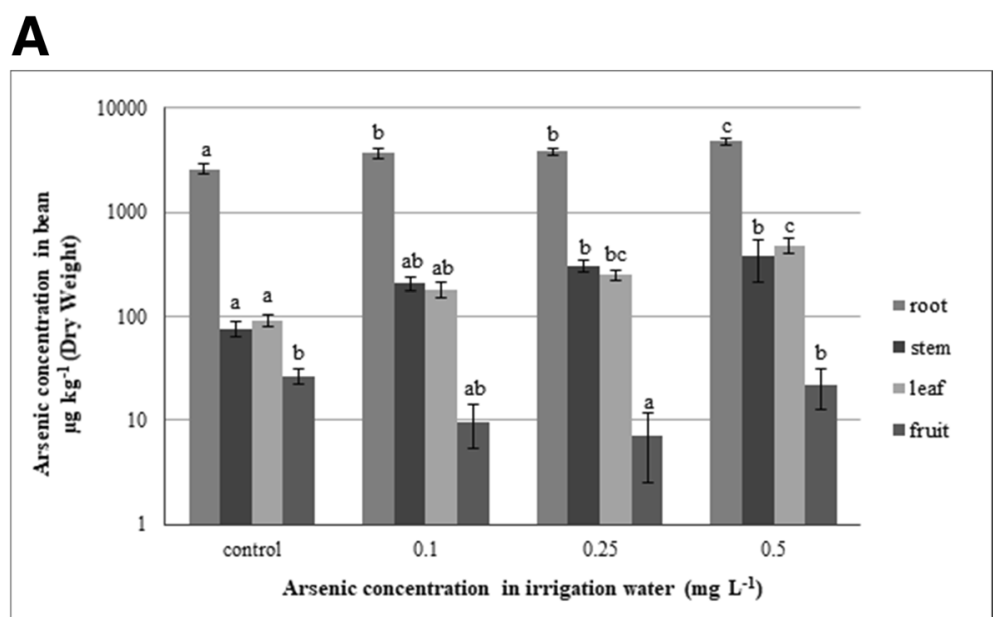

B

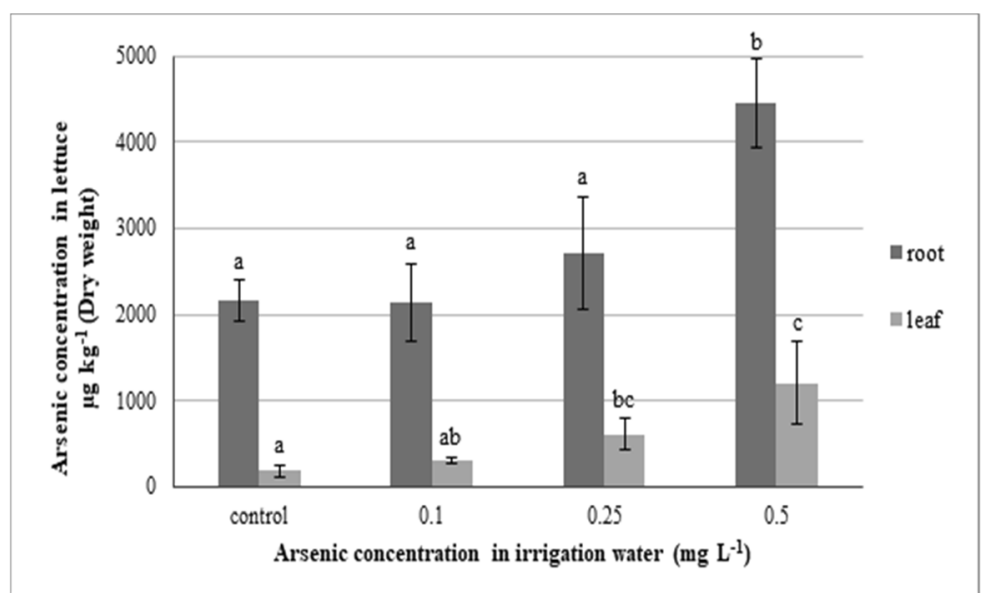

Fig. 2 As concentration in bean (a) and lettuce (b) plant parts at different As treatments: control, 0.1, 0.25, 0.5 $\mathrm{mg} \mathrm{L}^{-1}$ in the irrigation water. Different lowercase letter indicates significant differences among treatments in plant parts. Level of significance: $p<0.05$. Bars indicate standard deviation

Table 2 Concentration of macroelements and microelements in the edible part of bean, irrigated with water containing different arsenic c oncentrations [mg kg-1 DW (RSD\%)] $(n=5)$

\begin{tabular}{lllll}
\hline \multicolumn{4}{l}{ Concentrations $\mathrm{mg} \mathrm{kg}^{-1}$} & DW (RSD\%) \\
\hline Fruit & Control & $0.1 \mathrm{mg} \mathrm{L}^{-1}$ & $0.25 \mathrm{mg} \mathrm{L}^{-1}$ & $0.5 \mathrm{mg} \mathrm{L}^{-1}$ \\
\hline $\mathrm{Mg}$ & $251(6) \mathrm{a}$ & $259(7) \mathrm{b}$ & $249(6) \mathrm{b}$ & $234(6) \mathrm{b}$ \\
$\mathrm{P}$ & $337(11) \mathrm{a}$ & $360(9) \mathrm{b}$ & $322(7) \mathrm{ab}$ & $295(7) \mathrm{b}$ \\
$\mathrm{K}$ & $2557(10) \mathrm{a}$ & $3036(7) \mathrm{b}$ & $2604(7) \mathrm{b}$ & $2905(8) \mathrm{b}$ \\
$\mathrm{Fe}$ & $61(7) \mathrm{a}$ & $67(12) \mathrm{a}$ & $69(11) \mathrm{a}$ & $71(10) \mathrm{a}$ \\
$\mathrm{Mn}$ & $183(11) \mathrm{a}$ & $220(13) \mathrm{b}$ & $250(21) \mathrm{b}$ & $259(8) \mathrm{b}$ \\
$\mathrm{Cu}$ & $67(6) \mathrm{a}$ & $67(10) \mathrm{b}$ & $57(8) \mathrm{b}$ & $66(3) \mathrm{b}$ \\
$\mathrm{Zn}$ & $354(9) \mathrm{a}$ & $339(7) \mathrm{ab}$ & $387(14) \mathrm{b}$ & $385(14) \mathrm{b}$ \\
\hline
\end{tabular}

Table 3 Concentration of macroelements and microelements in the edible part of lettuce irrigated with water containing different arsenic concentrations [mg kg-1 DW (RSD\%)] $(n=5)$

\begin{tabular}{lllll}
\hline \multicolumn{4}{l}{ Concentrations $\mathrm{mg} \mathrm{kg}^{-1}$ DW (RSD\%) } \\
\hline Leaves & Control & $0.1 \mathrm{mg} \mathrm{L}^{-1}$ & $0.25 \mathrm{mg} \mathrm{L}^{-1}$ & $0.5 \mathrm{mg} \mathrm{L}^{-1}$ \\
\hline $\mathrm{Mg}$ & $657(17) \mathrm{a}$ & $602(19) \mathrm{a}$ & $662(17) \mathrm{a}$ & $580(19) \mathrm{a}$ \\
$\mathrm{P}$ & $244(6) \mathrm{a}$ & $207(26) \mathrm{a}$ & $169(20) \mathrm{a}$ & $298(15) \mathrm{a}$ \\
$\mathrm{K}$ & $2166(19) \mathrm{a}$ & $1421(9) \mathrm{a}$ & $2595(18) \mathrm{a}$ & $1541(21) \mathrm{a}$ \\
$\mathrm{Fe}$ & $155(21) \mathrm{a}$ & $162(16) \mathrm{a}$ & $172(24) \mathrm{a}$ & $350(26) \mathrm{a}$ \\
$\mathrm{Mn}$ & $46(12) \mathrm{a}$ & $36(17) \mathrm{a}$ & $39(12) \mathrm{a}$ & $51(27) \mathrm{a}$ \\
$\mathrm{Cu}$ & $6(6) \mathrm{a}$ & $8(12) \mathrm{a}$ & $6(14) \mathrm{a}$ & $9(20) \mathrm{a}$ \\
$\mathrm{Zn}$ & $36(4) \mathrm{a}$ & $41(11) \mathrm{a}$ & $40(9) \mathrm{a}$ & $35(11) \mathrm{a}$ \\
\hline
\end{tabular}


Table 4 Transfer factor for arsenic from root to the edible part in bean and lettuce irrigated with different concentration of arsenic containing water

\begin{tabular}{lllll}
\hline & Control & $0.1 \mathrm{mg} \mathrm{L}^{-1}$ & $0.25 \mathrm{mg} \mathrm{L}^{-1}$ & $0.5 \mathrm{mg} \mathrm{L}^{-1}$ \\
\hline Bean (root to shoot) & 0.08 & 0.11 & 0.14 & 0.18 \\
Bean (root to fruit) & 0.01 & 0.003 & 0.002 & 0.005 \\
Lettuce (root to leaf) & 0.08 & 0.14 & 0.23 & 0.24 \\
\hline
\end{tabular}

amount of As, indicating higher tolerance to As (Gonzalez et al. 2013). Similar results were also obtained by Arco-Lazaro et al. (2018) in lettuce where the plant accumulated As concentration as high as $1000 \mathrm{mg} \mathrm{kg}^{-1}$ without any phytotoxic effect and slight biomass loss. This behavior could be due to the plant inability to differentiate between $\mathrm{P}$ and As, thereby up-taking high amount of As through $\mathrm{P}$ channels. Gusman et al. (2013a) also reported an increase in lettuce biomass when exposed to low amount of As. This biomass increase could be due to increase in photosynthetic rate, caused by $\mathrm{P}$ nutrition. Higher $\mathrm{P}$ intake may occur due to As-induced $\mathrm{P}$ deficiency since As competes with $\mathrm{P}$ for uptake (Gusman et al. 2013a).

\section{Arsenic concentration in the plant parts and transfer factor}

In bean, As concentration of the fruit and root at the highest treatment was $22.1 \mu \mathrm{g} \mathrm{kg}^{-1}$ and $4797.1 \mu \mathrm{g} \mathrm{kg}{ }^{-1} \mathrm{DW}$, respectively. Caporale et al. (2013) reported the As concentration in bean fruit in the range $0.64-1.08 \mathrm{mg} \mathrm{kg}^{-1}$ DW while the roots contained $1.16-4.79 \mathrm{mg} \mathrm{kg}^{-1} \mathrm{DW}$. Sadee et al. (2016) reported bean fruit As concentration to be $0.133 \mathrm{mg} \mathrm{kg}^{-1} \mathrm{DW}$. The low bean fruit As concentration in our study could be due to lower As treatments applied and lower soil As. In lettuce, the leaf and root As concentration was $1207.5 \mu \mathrm{g} \mathrm{kg}^{-1}$ and $4445.6 \mu \mathrm{g} \mathrm{kg}{ }^{-1} \mathrm{DW}$, respectively. Bergqvist et al. (2014) reported lower As concentration in lettuce leaves and roots $\left(0.29 \mathrm{mg} \mathrm{kg}^{-1}\right.$ and $1.02 \mathrm{mg} \mathrm{kg}^{-1} \mathrm{DW}$ respectively), due to low soil As concentration of $2.2 \mathrm{mg} \mathrm{kg}^{-1}$. Higher values for lettuce leaf As were reported by Smith et al. (2009) $\left(3.18 \mathrm{mg} \mathrm{kg}^{-1} \mathrm{DW}\right)$ in hydroponics, and Tremlova et al. (2017) $\left(4.5 \mathrm{mg} \mathrm{kg}^{-1} \mathrm{DW}\right)$ in soil contaminated by mining and smelting (Tremlova et al. 2017).

In the present study, in both plants, the maximum As concentration was found in the roots and the minimum at the end of phloem distribution pathway (fruit or leaf). Similar observation has been reported in beans (Caporale et al. 2013), tomato (Carbonell-Barrachina et al. 1998; Stazi et al. 2016) lettuce and radish (Smith et al. 2009). Plants in general prevent toxic compounds from reaching photosynthetic tissues, and thus, As concentrations in roots are about 5-20 times higher than in shoots (Lindsay
\& Matthuis 2017). Plants alleviate toxicity by binding As to the $-\mathrm{SH}$ (sulfahydryl) groups of thiols and sequester the As-PC (phytochelatin) complex in the root vacuoles, thus reducing the translocation to aerial parts (Ronzan et al. 2017). In both bean and lettuce, increase in the As treatment applied caused an increase in the As concentration in all plant parts. The As concentration of the roots increased due to absorption. The stem As concentration was lower than the As concentration of both roots and leaves, indicating that a large portion of the absorbed As remained bound in the roots unavailable for translocation. As uptake and accumulation depends on the plant habitat, species and on morphological features like root length and diameter, and root hair (Abedin et al. 2002; Farooq et al. 2016). The amount of As in the edible part is proportional to the amount present in the roots, indicating that As translocation to the fruit and leaves depended on the amount present in the roots and shoot. Lettuce has higher As concentration in edible part as compared to bean due to broader leaf area and higher transpiration which results in significant translocation and accumulation of metals and metalloids (Chang et al. 2014). Ramirez-Andreotta et al. (2013) reported that there was significant correlation between As uptake in the edible tissue of vegetables families and the level of As in the soil for some plant families like Asteraceae (lettuce) and Fabaceae (bean).

Transfer factor is a measure of the plants efficiency to transport an element from root to shoot. On the basis of literature data (Melo et al. 2009; Stazi et al. 2016) and our results, it can be stated that the root: fruit TF values generally are very low (0.001-0.1), because As bioaccumulation in hazardous amounts rarely occurs in plants due to its phytotoxicity (Warren et al. 2003). In case of leafy vegetables, the root: shoot TF values are in the range of 0.1-0.7 (Tremlova et al. 2017; Bergqvist et al. 2014). Low TFs could be a mechanism of the plants to prevent the photosynthetic tissues from being damaged (Uroic et al. 2012; Bergqvist et al. 2014).

\section{Recommended maximum as concentration in irrigation water}

Human exposure to As via plants depends on the ability of plant to uptake and translocate As to the edible parts as well as on the amount consumed and frequency of consumption (Huang et al. 2006). The FAO-WHO recommended maximum tolerable daily intake (MTDI) limit for As is $2.1 \mu \mathrm{g} \mathrm{kg}^{-1}$ body weight (FAO-WHO 1988), thus the daily intake limit for a person weighing $70.8 \mathrm{~kg}$ would be $142 \mu \mathrm{g}$. Arsenic accumulation in the bean fruit was much lower than in the lettuce leaves $\left(22.1 \mu \mathrm{g} \mathrm{kg}^{-1}\right.$ and $\left.1207.5 \mu \mathrm{g} \mathrm{kg}^{-1} \mathrm{DW}\right)$, respectively, at $0.5 \mathrm{mg} \mathrm{L}^{-1}$ As treatment. If a person consumes $450 \mathrm{~g}$ (FW, 80\% moisture) of bean or lettuce then their total As intake would be $1.98 \mu \mathrm{g}$ from bean and $108.7 \mu \mathrm{g}$ from 
lettuce, respectively. Considering the daily intake limit, in case of beans the value is within the permissible limit but in case of lettuce the value borders the permissible limit. If the As intake from water, milk, cereals and other foods are considered then the As consumption from lettuce would be very high. In bean, the biomass production decreased beyond treatment dosage of $0.1 \mathrm{mg} \mathrm{L}^{-1}$ (as mentioned in subchapter 3.2) thus, it would be profitable to grow beans at not more than $0.1 \mathrm{mg} \mathrm{L}^{-1} \mathrm{As}$ concentration. Lettuce at $0.5 \mathrm{mg} \mathrm{L}^{-1}$ As treatment produced the maximum biomass but considering the MTDI limit, it would be harmful to consume lettuce irrigated at As concentrations higher than $0.1 \mathrm{mg} \mathrm{L}^{-1}$. Therefore, it is recommended for farmers that growing lettuce or other leafy vegetables in a calcareous sandy soil with irrigation water containing As concentration of more than $0.1 \mathrm{mg} \mathrm{L}^{-1}$ carries a contamination risk.

\section{Effect of arsenic on the investigated macroelements and microelements profile in the edible plant part}

Arsenic causes toxic effect in the plant by producing reactive oxygen species (ROS) which damage the cell membrane, hinder metabolism, reduce growth and alter the nutrient balance (Koo et al. 2011; Gusman et al. 2013b). In our study, the Mg concentration of the bean fruit and lettuce leaf decreased with higher As treatment. $\mathrm{Mg}$, the central atom in the chlorophyll molecule and helps in counteracting As toxicity, is required for enzyme activation, phosphorylation and photosynthesis (Marshner 1998). Carbonell-Barrachina et al. (1998) also reported a similar decrease in tomato leaf $\mathrm{Mg}$ concentration. Quanji et al. (2008) reported an increase in $\mathrm{Mg}$ translocation to the shoots and leaves of wheat when supplied with higher As treatments. P concentration decreased in bean fruit and increased in lettuce leaves with higher As treatment. $\mathrm{P}$ is a major macronutrient for plant growth and is involved in key functions like energy transfer, photosynthesis and nutrient movement in plant (Marshner 1998). Decrease in P concentration has also been observed in rice (Quanji et al. 2008) while in Ipomoea aquatica no change was observed (Shaibur et al. 2009). The change in $P$ concentration in bean fruit and lettuce leaf is probably due to change in their respective biomass production. $\mathrm{K}$ concentration in the bean fruit increased while in lettuce leaves it decreased. $\mathrm{K}$ is essential for cell division, cell turgor, electroneutrality and strong stems (Haque et al. 2009; Gusman et al. 2013b). The increase in $\mathrm{K}$ concentration in bean fruit could be due to synergistic relation between inorganic As compounds and $\mathrm{K}$ in the soil solution to maintain ionic balance. It could also be because plants maintain a relatively constant supply of $3 \mathrm{~g} \mathrm{~kg}^{-1}$ of $\mathrm{K}$ to the grains and seeds, even in deficiency conditions (Marshner 1998; Quanji et al. 2008). Fe concentration in both bean and lettuce increased with increasing As treatment. Fe is an essential plant nutrient having high As affinity and thereby acting as As sink. Fe in leaf tissues is involved in protein and chlorophyll synthesis, which explains the higher Fe content of lettuce leaves (Marshner 1998). Similar behavior was observed in lettuce plants by Gusman et al. (2013b). Low P might help mobilize Fe in shoot thereby maintaining the chlorophyll index. The increase in Fe could also be due to Fe-plaque formation on the root surface, which acts as a As sink (Gusman et al. 2013b). Mn shows an increasing tendency in both bean and lettuce, but the increase is more pronounced in case of bean. Mn is involved in the activity of certain enzymes and in photosynthesis. Shaibur et al. (2009) reported an inverse relationship between $\mathrm{Mn}$ and As in Ipomoea aquatica. $\mathrm{Cu}$ concentration in both plants varies slightly at all treatments, but bean $\mathrm{Cu}$ concentration is much higher than lettuce. Cu plays a role in photosynthesis, respiration, $\mathrm{C}$ and $\mathrm{N}$ metabolism, protection against oxidative stress and acts as a catalyst of redox reactions. Similar results for $\mathrm{Cu}$ concentration have been observed in lettuce and potato by Khan et al. (2019). Zn concentration in bean shows an increasing trend while in lettuce it does not change significantly. $\mathrm{Zn}$ impacts transpiration, enzyme activation and protein synthesis (Marshner 1998). This trend was also observed in lettuce leaves and potato (Khan et al. 2019) and rice grains (Dwivedi et al. 2010). High $\mathrm{Zn}$ in bean fruit could be due to high presence of $\mathrm{Zn}$ in phloem sap.

\section{Conclusions}

From the current study it can be concluded that lettuce leaves have higher As concentration as compared to the bean fruit. On the basis of the MTDI, at $0.5 \mathrm{mg} \mathrm{L}^{-1}$ As concentration in the irrigation water, the As intake from bean would be very less, but the As intake from lettuce could exceed the daily intake limit. Thus, it would be safe to consume bean harvested at all treatment levels employed in this study, but lettuce cultivated at concentrations higher than $0.1 \mathrm{mg} \mathrm{L}^{-1}$ could be harmful. Increase in As concentration of the irrigation water caused an increase in the As accumulation in both plants, with the maximum As concentration occurring in the roots and the minimum in the bean fruit. Lettuce accumulated higher amount of As without any phytotoxic symptoms or any impact on the plant biomass, but in bean the edible biomass productivity decreased. No significant changes were observed in the concentration of the essential macro and microelements possibly due to the low level of As treatment applied. Considering the As concentration in edible plant parts and biomass productivity, it is recommended to cultivate bean and lettuce with 
irrigation water having a maximum As concentration of $0.1 \mathrm{mg} \mathrm{L}^{-1}$. These observations are valid only for calcareous sandy soil used in this study. Further investigation will be extended to a variety of vegetables and soil types to help establish a database for the farmers, so that they can make an informed decision while choosing a plant for cultivation.

\author{
Abbreviations \\ BW: Body Weight; CEC: Cation Exchange Capacity; CRM: Certified Reference \\ Material; DM: Dry Matter; DW: Dry weight; EFSA: European Food Safety \\ Authority; FAO-WHO: Food and Agriculture Organization-World Health \\ Organization; FW: Fresh Weight; HAS: Hungarian Academy of Sciences; ICP- \\ MS: Inductively Coupled Plasma-Mass Spectrometer; INTs: Inositol \\ Transporters; JECFA: Joint WHO/FAO Expert Committee on Food Additives: \\ MSZ: Hungarian Standards; MTDI: Maximum Tolerable Daily Intake; \\ NIP: Nodulin Intrinsic Protein; NIST: National Institute of Standards and \\ Technology; OM: Organic Matter; PCs: Phytochellatin; ROS: Reactive Oxygen \\ Species; SH: Sulfhydryl; TF: Transfer Factor; WHO: World Health \\ Organization As Arsenic
}

\section{Acknowledgements}

This research was supported by the Hungarian Scientific Research Foundation grant, NVKP_16-1-2016-0044.

\section{Authors' contributions}

All authors contributed to the analysis, writing and improvement of the manuscript. All authors read and approved the final manuscript.

\section{Funding}

This research was supported by the Hungarian Scientific Research Foundation grant, NVKP_16-1-2016-0044.

\section{Availability of data and materials}

The data sets on which the conclusions of the paper rely is presented in the main body of the manuscript.

\section{Competing interests}

The authors declare that they have no competing interests.

\section{Author details}

'MTA Centre for Ecological Research, Danube Research Institute, Karolina út 29-31, Budapest $\mathrm{H}-1113$, Hungary. ${ }^{2}$ Cooperative Research Centre of Environmental Sciences, Eötvös Loránd University, Pázmány Péter sétány 1/A, Budapest $\mathrm{H}-1117$, Hungary. ${ }^{3}$ MTA Centre for Agricultural Research, Institute for Soil Sciences and Agricultural Chemistr, Herman Ottó út 15, Budapest $\mathrm{H}-1022$, Hungary.

Received: 30 September 2019 Accepted: 3 December 2019

Published online: 27 December 2019

\section{References}

Abedin, M. J., Feldmann, J., \& Meharg, A. A. (2002). Uptake kinetics of arsenic species in rice plants. Plant Physiology, 128(3), 1120-1128.

Arco-Lazaro, E., Pardo, T., Clemente, R., \& Bernal, M. P. (2018). Arsenic adsorption and plant availability in an agricultural soil irrigated with as-rich water: Effects of Fe-rich amendments and organic and inorganic fertilizers. Journal of Environmental Management, 209, 262-272.

Ascher, J., Ceccherini, M. T., Landi, L., Mench, M., Pietramellara, G., Nannipieri, P., \& Renella, G. (2009). Composition, biomass and activity of microflora, and leaf yields and foliar elemental concentrations of lettuce, after in situ stabilization of an arsenic-contaminated soil. Applied Soil Ecology, 41, 351-359.

Awasthi, S., Chauhan, R., Srivastava, S., \& Tripathi, R. D. (2017). The journey of arsenic from soil to grain in rice. Frontiers in Plant Science, 8, 1007. https://doi. org/10.3389/fpls.2017.01007.

Bakhat, H. F., Zia, Z., Fahad, S., Abbas, S., Hammad, H. M., Shahzad, A. N., Abbas, F. Alharby, H., \& Shahid, M. (2017). Arsenic uptake, accumulation and toxicity in rice plants: Possible remedies for its detoxification: A review. Environmental Science and Pollution Research, 24(10), 9142-9158.
Bergqvist, C., Herbert, R., Persson, I., \& Greger, M. (2014). Plants influence on arsenic availability and speciation in the rhizosphere, roots and shoots of three different vegetables. Environmental Pollution, 184, 540-546.

Brammer, H., \& Ravenscroft, P. (2009). Arsenic in groundwater: A threat to sustainable agriculture in south and south-East Asia. Environment International, 35, 647-654.

Caporale, A. G., Pigna, M., Sommella, A., Dynes, J. J., Cozzolino, V., \& Violante, A. (2013). Influence of compost on mobility of arsenic in soil and its uptake by bean plants (Phaseolus vulgaris $L$.) irrigated with arsenite contaminated water. Journal of Environmental Management, 128, 837-843.

Carbonell-Barrachina, A. A., Burlo, F., Lopez, E., \& Mataix, J. (1998). Tomato plant nutrition as affected by arsenite concentration. Journal of Plant Nutrition, 21(2), 235-244

Chang, C. Y., Yu, H. Y., Chen, J. J., Li, F. B., Zhang, H. H., \& Liu, C. P. (2014). Accumulation of heavy metals in leaf vegetables from agricultural soils and associated potential health risks in the Pearl River Delta, South China. Environmental Monitoring and Assessment, 186, 1547-1560.

Das, H. K., Mitra, A. K., Sengupta, P. K., Hossain, A., Islam, F., \& Rabbani, G. H. (2004). Arsenic concentrations in rice, vegetables and fish in Bangladesh: A preliminary study. Environment International, 30, 383-387.

Dwivedi, S., Tripathi, R. D., Srivastava, S., Singh, R., Kumar, A., Tripathi, P., Dave, R., Rai, R. N., Chakrabarty, D., Trivedi, P. K., Tuli, R., Adhikari, B., \& Bag, M. K. (2010). Arsenic affects minerals nutrients in grains of various Indian rice (Oryza sativa L.) genotypes grown on arsenic contaminated soils of West Bengal. Protoplasma, 245, 113-124.

Scientific Opinion on Arsenic in Food, EFSA Panel on Contaminants in the Food Chain (CONTAM), European Food Safety Authority, Parma, Italy. Retrieved from https:/efsa.onlinelibrary.wiley.com/doi/epdf/10.2903/j.efsa.2009.1351.

Egnér, H., Riehm, H., \& Domingo, W. R. (1960). Investigations on chemical soil analysis as the basis for estimating soil fertility and chemical extraction methods for phosphorus and potassium determination. Kungl Landbrukshögsk Annaler (German), 26, 199-215.

FAO-WHO. (1988). Joint FAOMHO expert committee on food additives. Food and Agriculture Organization of the United Nations, Rome, Italy / World Health Organization, Geneva, Switzerland. Retrieved from https://www.who.int/ foodsafety/areas_work/chemical-risks/jecfa/en/.

Farooq, M. A., Islam, F., Ali, B., Najeeb, U., Mao, B., Gill, R. A., Yan, G., Siddique, K. H. M., \& Zhou, W. (2016). Arsenic toxicity in plants: Cellular and molecular mechanisms of its transport and metabolism. Environmental and Experimental Botany, 132, 42-52.

Gonzalez, V., Simon, M., Garcia, I., Sanchez, J. A., \& Moral, F. (2013). Effectiveness of amendments to restore metal-arsenic-polluted soil functions using Lactuca sativa L. bioassays. Journal of Soils and Sediments, 13, 1213-1222.

Gusman, G. S., Oliveira, J. A., Farnese, F. S., \& Cambraia, J. (2013a). Arsenate and arsenite: The toxic effects on photosynthesis and growth of lettuce plants. Acta Physiologiae Plantarum, 35, 1201-1209.

Gusman, G. S., Oliveira, J. A., Farnese, F. S., \& Cambraia, J. (2013b). Mineral nutrition and enzymatic adaptation induced by arsenate and arsenite exposure in lettuce plants. Plant Physiology and Biochemistry, 71, 307-314.

Haque, N., Peralta-Videa, J. R., Duarte-Gardea, M., \& Gardea-Torresdey, J. L. (2009). Differential effect of metals/metalloids on the growth and element uptake of mesquite plants obtained from plants grown at a copper mine tailing and commercial seeds. Bioresource Technology, 100, 6177-6182.

Huang, R. Q., Gao, S. F., Wang, W. L., Staunton, S., \& Wang, G. (2006). Soil arsenic availability and the transfer of soil arsenic to crops in suburban areas in Fujian province, Southeast China. Science of the Total Environment, 368, 531-541.

Huq, S. M. I., Joardar, J. C., Parvin, S., Correll, R., \& Naidu, R. (2006). Arsenic contamination in food chain: Transfer of arsenic into food materials through groundwater irrigation. Journal of Health, Population and Nutrition, 24(3), 305-316.

Joint FAO/WHO Expert Committee on Food Additives, Food and Agriculture Organization of the United Nations, Rome, Italy/ World Health Organization, Geneva, Switzerland. Retrieved from http://apps.who.int/food-additivescontaminants-jecfa-database/search.aspx.

Juhasz, A. L., Smith, E., Weber, J., Rees, M., Rofe, A., Kuchel, T., Sansom, L., \& Naidu, R. (2008). Application of an in vivo swine model for the determination of arsenic bioavailability in contaminated vegetables. Chemosphere, 71, 1963-1969.

Khan, A., Khan, S., Khan, M. A., Aamir, M., Ullah, H., Nawab, J., Rehman, I. U., \& Shah, J. (2019). Heavy metals effects on plant growth and dietary intake of 
trace metals in vegetables cultivated in contaminated soil. International journal of Environmental Science and Technology, 16, 2295-2304.

Koo, N., Jo, H. J., Lee, S. H., \& Kim, J. G. (2011). Using response surface methodology to assess the effects of iron and spent mushroom substrate on arsenic phytotoxicity in lettuce (Lactuca sativa). Journal of Hazardous Materials, 192, 381-387.

Lazaro, E. A., Pardo, T., Clemente, R., \& Bernal, M. A. (2018). Arsenic adsorption and plant availability in an agricultural soil irrigated with As-rich water: Effects of Fe-rich amendments and organic and inorganic fertilizers. Journal of Environmental Management, 209, 262-272.

Lindsay, E. R., \& Matthuis, J. M. (2017). New molecular mechanisms to reduce arsenic in crops. Trends in Plant Science, 22(12), 1016-1026.

Lu, Y., Dong, F., Deacon, C., Chen, H., Raab, A., \& Meharg, A. A. (2010). Arsenic accumulation and phosphorus status in two rice (Oryza sativa L.) cultivars surveyed from fields in South China. Environmental Pollution, 158, 1536-1541.

Malik, J. A., Goel, S., Kaur, N., Sharma, S., Singh, I., \& Nayyar, H. (2012). Selenium antagonizes the toxic effects of arsenic on mung beans (Phaseolus aureus Roxb.) plants by restricting its uptake and enhancing the antioxidative and detoxification mechanisms. Environmental and Experimental Botany, 77, 242-248.

Marshner, H. (1998). Mineral nutrition of higher plants. London: Academic.

Melo, E. E. C., Costa, E. T. S., Guilherme, L. R. G., Faquin, V., \& Nascimento, C. W. A. (2009). Accumulation of arsenic and nutrients by castor bean plants grown on an As-enriched nutrient solution. Journal of Hazardous Materials, 168, 479-483.

Mirza, N., Mahmood, Q., Shah, M. M., Pervez, A., \& Sultan, S. (2014). Plants as useful vectors to reduce environmental toxic arsenic content. The Scientific World Journal., 2014, 921581. https://doi.org/10.1155/2014/921581.

Oliveira, L. M., Suchismita, D., Gress, J., Rathinasabapathi, B., Chen, Y., \& Ma, L. Q. (2017). Arsenic uptake by lettuce from As-contaminated soil remediated with Pteris vittata and organic amendment. Chemosphere, 176, 249-254.

Otero, X. L., Tierra, W., Atiaga, O., Guanoluisa, D., Nunes, L. M., Ferreira, T. O., \& Ruales, J. (2016). Arsenic in rice agrosystems (water, soil and rice plants) in Guayas and Los Rios provinces, Ecuador. Science of the Total Environment, 573, 778-787.

Quanji, L., Chengxiao, H., Qiling, T., Xuecheng, S., Jingjun, S., \& Yuexiang, L. (2008). Effects of As on As uptake, speciation, and nutrient uptake by winter wheat (Triticum aestivum L.) under hydroponic conditions. Journal of Environmental Sciences, 20, 326-331

Ramirez-Andreotta, M. D., Brusseau, M. L., Artiola, J. F., \& Maier, R. M. (2013). A greenhouse and field-based study to determine the accumulation of arsenic in common homegrown vegetables grown in mining-affected soils. Science of the Total Environment, 443, 299-306.

Ronzan, M., Zanella, L., Fattorini, L., Rovere, F. D., Urgast, D., Cantamessa, S., Nigro, A., Barbieri, M., Sanita di Toppi, L., Berta, G., Feldmann, J., Altamura, M. M., \& Falasca, G. (2017). The morphogenic responses and phytochelatin complexes induced by arsenic in Pteris vittata change in the presence of cadmium. Environmental and Experimental Botany, 133, 176-187.

Sadee, B. A., Foulkes, M. E., \& Hill, S. J. (2016). A study of arsenic speciation in soil, irrigation water and plant tissue: A case study of the broad bean plant, Vicia faba. Food Chemistry, 210, 362-370.

Sahoo, P. K., \& Kim, K. (2013). A review of the arsenic concentration in paddy rice from the perspective of geoscience. Geosciences Journal, 17(1), 107-122.

Saifullah, Dahlawi, S., Naeem, A., lqbal, M., Farooq, M. A., Bibi, S., \& Rengel, Z. (2018). Opportunities and challenges in the use of mineral nutrition for minimizing arsenic toxicity and accumulation in rice: A critical review. Chemosphere, 194, 171-188.

Santra, S. C., Samal, A. C., Bhattacharya, P., Banerjee, S., Biswas, A., \& Majumdar, J. (2013). Arsenic in food chain and community health risk: A study in Gangetic West Bengal. Procedia Environmental Sciences, 18, 2-13.

Sarkar, A., \& Paul, B. (2016). The global menace of arsenic and its conventional remediation- a critical review. Chemosphere, 158, 37-49.

Shaibur, M. R., Islam, T., \& Kawai, S. (2009). Response of leafy vegetable Kalmi (water spinach: Ipomoea aquatic L.) at elevated concentrations of arsenic in hydroponics culture. Water, Air, and Soil Pollution, 202, 289-300.

Shaibur, M. R., \& Kawai, S. (2009). Effects of arsenic on visible symptoms and arsenic concentration in hydroponics Japanese mustard spinach. Environmental and Experimental Botany, 67, 65-70.

Shaibur, M. R., Kitajima, N., Sugawara, R., Kondo, T., Alma, S., Huq, S. M. I., \& Kawai, S. (2008). Critical toxicity level of arsenic and elemental composition of arsenic-induced chlorosis in hydroponic Sorghum. Water, Air, and Soil Pollution, 191, 279-292.
Signorell, A. (2018). Tools for descriptive statistics. Package DescTools. Retrieved from https://cran.r-project.org/web/packages/DescTools/DescTools.pdf.

Smith, E., Juhasz, A. L., \& Weber, J. (2009). Arsenic uptake and speciation in vegetables grown under greenhouse conditions. Environmental Geochemistry and Health, 31, 125-132.

Stazi, S., Cassaniti, C., Marabottini, R., Giuffrida, F., \& Leonardi, C. (2016). Arsenic uptake and partitioning in grafted tomato plants. Horticulture, Environment, and Biotechnology, 57(3), 241-247.

Stoeva, N., Berova, M., \& Zlatev, Z. (2005). Effect of arsenic on some physiological parameters in bean plants. Biologia Plantarum, 49(2), 293-296.

Tremlova, J., Sehnal, M., Szakova, J., Goessler, W., Steiner, O., Najmanova, J., Horakova, T., \& Tlustos, P. (2017). A profile of arsenic species in different vegetables growing in arsenic-contaminated soils. Archives of Agronomy and Soil Science, 63(7), 918-927. https://doi.org/10.1080/03650340.2016.1242721.

Uddh-Soderberg, T. E., Gunnarsson, S. J., Hogmalm, K. J., Boel, M. I., Lindegard, G., \& Augustsson, A. L. M. (2015). An assessment of health risks associated with arsenic exposure via consumption of homegrown vegetables near contaminated glassworks sites. Science of the Total Environment, 536, 189-197.

Uroic, M. K., Salaün, P., Raab, A., \& Feldman, J. (2012). Arsenate impact on the metabolite profile, production, and arsenic loading of xylem sap in cucumbers (Cucumis sativus L.). Front Physiol, 3, 55. https://doi.org/10.3389/ fphys.2012.00055

Varsanyi, I., \& Kovacs, L. O. (2006). Arsenic, iron and organic matter in sediments and groundwater in the Pannonian Basin, Hungary. Applied Geochemistry, 21(6), 949-962.

Warren, G. P., Alloway, B. J., Lepp, N. W., Singh, B., Bochereau, F. J. M., \& Penny, C. (2003). Field trials to assess the uptake of arsenic by vegetables from contaminated soils and soil remediation with iron oxides. Science of the Total Environment, 311, 19-33.

WHO. (1993). Arsenic in drinking-water, background document for development of WHO guidelines for drinking-water quality. Geneva, Switzerland: World Health Organization Retrieved from https://www.who.int/.

\section{Publisher's Note}

Springer Nature remains neutral with regard to jurisdictional claims in published maps and institutional affiliations.

Ready to submit your research? Choose BMC and benefit from:

- fast, convenient online submission

- thorough peer review by experienced researchers in your field

- rapid publication on acceptance

- support for research data, including large and complex data types

- gold Open Access which fosters wider collaboration and increased citations

- maximum visibility for your research: over $100 \mathrm{M}$ website views per year

At $\mathrm{BMC}$, research is always in progress.

Learn more biomedcentral.com/submissions 